\title{
Retardation of Secretory Capacity of Immature Rat Parotid Gland by Chronic Administration of Isoproterenol
}

\author{
CHARLOTTE A. SCHNEYER ${ }^{121}$ \\ Department of Physiology and Biophysics, University of Alabama in Birmingham, Birmingham, Alabama, USA
}

\begin{abstract}
Summary
The present findings show that while chronic administration of the catecholamine isoproterenol to immature rats causes accelerated structural development, it causes an inhibition of certain aspects of secretory function. The effects on both structure and function are however closely dependent on the stage of development during which the agent is administered. When the isoproterenol is given for 8 days between 12 and 20 days of age, amylase, $\mathrm{Na}$, and $\mathrm{K}$ concentrations of pilocarpine-evoked parotid saliva of the treated and control littermates are similar. If, however, the agent is given between 22 and 30 days of age, amylase of the isoproterenol-treated glands is only one-fourth that of controls, and $\mathrm{K}$ concentration is higher than that of controls whereas $\mathrm{Na}$ is lower. The glands of controls in both pre- and postweanling groups produce greater volumes of water than do isoproterenol-treated glands. Developmentally, these data represent less advanced secretory abilities, and therefore isoproterenol induces inhibition of secretory capacity, rather than enhancement.
\end{abstract}

\section{Speculation}

Drugs administered during early postnatal growth may possibly irrevocably modify critical components of function.

At birth the parotid of rat is not fully developed $(2,8)$ and growth and differentiation of salivary glands continue for at least another 6 weeks $(2)$. The morphologic $(8,9)$ and biochemical differentiation $(1,3,10)$ of the parotid can be accelerated if large doses of the catecholamine, isoproterenol, are chronically administered. To what extent the secretory capacity of these precociously developed glands is also altered has not been established although it has been shown that gland levels of amylase are prematurely elevated in such glands (5). The present work was undertaken to see if other aspects of secretory function are also precociously altered, especially at times during normal postnatal development when morphologic and growth changes are pronounced (7).

\section{MATERIALS AND METHODS}

Long-Evans rats, varying in age from 8-66 days, were used in these experiments. Food but not water was removed from animals $12-28 \mathrm{hr}$ before acute experimentation. $l$-Isoproterenol in doses of $16 \mathrm{mg} / \mathrm{kg}$ were administered in saline ip twice daily for 8 days, to half of each litter, and the remaining half of the litter was injected only with equal volumes of saline. Secretion from the parotid was elicited by ip injection of pilocarpine nitrate $(5 \mathrm{mg} / \mathrm{kg})$. Na and $\mathrm{K}$ concentrations of the saliva were measured using an IL flame photometer; wet weight of parotid gland was measured using a torsion balance, and volume of saliva was measured, as well as flow rate (microliters per min per mg wet tissue). Amylase activity was measured by the method of Myers et al. (4).

\section{RESULTS}

The composition of pilocarpine-evoked saliva from parotid gland of control neonatal rats differed significantly from that obtained from glands of litter mates chronically treated with isoproterenol. Furthermore, the postnatal period during which the agent was administered critically modified the direction of the changes. Thus, when isoproterenol was administered to preweanling rats for 8 days, and the initial isoproterenol injection given at 12 days of age, neither $\mathrm{K}, \mathrm{Na}$, nor amylase concentration of the saliva of such animals was higher than that of untreated controls $(P>0.05)$ (Table 1). However, when volumes of saliva were compared, the control glands produced approximately 2 times as much fluid per min as did the glands of isoproterenol-treated animals. This was especially surprising since gland weight of the controls was only half that of the glands of isoproterenol-treated animals. In accord with these differences, flow rate, of control glands, when expressed as microliters per min per mg wet tissue, was about 4-5 times greater than that of glands of isoproterenoltreated animals.

The chronic administration of isoproterenol to postweanling rats has different effects from those on the preweanling rats. Thus, rats 32 days of age at time of sacrifice and 22 days of age at time of initial injection of isoproterenol exhibited a marked increase in gland weight after 8 days of drug administration when comparison was made with control littermates. The change in weight was nearly 5-fold. In this age group volume of saliva produced by control parotids in response to pilocarpine stimulation was slightly greater than that produced by the glands of isoproterenol-treated rats. The differences in flow rate (microliters per min per $\mathrm{mg}$ ) were, however, very marked in this age group because the glands showed a greater increase in size. Both $\mathrm{K}$ and $\mathrm{Na}$ concentration of the evoked salivas from the treated and control rats differed from each other and while both exhibited the usual age-related increase in $\mathrm{Na}$ and decrease in $\mathrm{K}$ (7), the saliva from the isoproterenol-treated glands more closely resembled that of younger animals than did the saliva of controls. $\mathrm{K}$ concentration was still relatively high $(38 \mathrm{mEq} /$ liter in the glands of isoproterenol-treated rats and $25 \mathrm{mEq} /$ liter in that of controls). $\mathrm{Na}$ concentration of saliva from control glands was $17 \%$ greater than that of saliva from isoproterenol-treated animals (Table 1). Amylase concentration of the pilocarpine-evoked saliva from glands of isoproterenoltreated rats was only about one-fourth the level of controls (60 $\mathrm{mg} / \mathrm{mg}$ as compared with $220 \mathrm{mg} / \mathrm{mg}$ ).

The persistence of effects induced by isoproterenol was also examined. Groups of rats were placed on isoproterenol at 4 days of age and thereafter maintained on isoproterenol for 32 days. Gland size of isoproterenol-treated rats was only twice as great as that of controls; this was in sharp contrast to the 4- to 5-fold increases observed in the 22-32 day age group when the period of isoproterenol administration was much shorter (8 days). Volume of saliva from parotid of isoproterenol-treated rats was only onehalf that of untreated animals, and flow rate (milligrams per min 
Table 1. Effects of chronic administration of isoproterenol (ISO) on volume, $\mathrm{Na}, \mathrm{K}$, and amylase of pilocarpine-evoked saliva from parotid $(P A)$ of immature rats ${ }^{1}$

\begin{tabular}{|c|c|c|c|c|c|c|c|c|}
\hline \multirow[b]{2}{*}{ Conditions before exp } & \multirow{2}{*}{$\begin{array}{l}\text { Age at } \\
\text { sacri- } \\
\text { fice. } \\
\text { days }\end{array}$} & \multirow[b]{2}{*}{$\begin{array}{l}\text { No. days } \\
\text { on ISO }\end{array}$} & \multirow[b]{2}{*}{ PA wt. (mg) } & \multicolumn{2}{|c|}{ Flow rate } & \multicolumn{3}{|c|}{ Concentration } \\
\hline & & & & $\mu \mathrm{l} / \mathrm{min}$ & $\mu \mathrm{l} / \mathrm{min} \cdot \mathrm{mg}$ & $\begin{array}{c}\mathrm{Na} \\
\mathrm{mEq} / \text { liter }\end{array}$ & K. mEq/liter & $\begin{array}{l}\text { Amylase ac- } \\
\text { tivity } \mathrm{mg} / \mathrm{mg}\end{array}$ \\
\hline $\begin{array}{l}\text { F. } 12 \mathrm{hr} \text { last inj. ISO } 18 \\
\text { hr before sacrifice }\end{array}$ & 21 & 8 & $102 \pm 1.3(7)$ & $1.40 \pm 0.05$ & $0.014 \pm 0.001$ & $50 \pm 6.2$ & $52 \pm 1.2$ & $25 \pm 5.0$ \\
\hline $\begin{array}{l}\mathrm{F}, 12 \mathrm{hr} \text { : last inj. saline } 18 \\
\mathrm{hr} \text { before sacrifice }\end{array}$ & 21 & 0 & $59 \pm 3.7(6)$ & $2.94 \pm 0.06$ & $0.049 \pm 0.003$ & $50 \pm 9.8^{*}$ & $46 \pm 2.3^{*}$ & $44 \pm 16.0^{*}$ \\
\hline $\begin{array}{l}\text { F. } 18 \mathrm{hr} \text { last inj. ISO } 36 \\
\text { hr before sacrifice }\end{array}$ & 32 & 8 & $474 \pm 38(5)$ & $3.34 \pm 0.07$ & $0.007 \pm 0.002$ & $89 \pm 2.7$ & $38 \pm 2.4$ & $56 \pm 15.9$ \\
\hline $\begin{array}{l}\mathrm{F}, 18 \mathrm{hr} \text { : last inj. saline } 18 \\
\mathrm{hr} \text { before sacrifice }\end{array}$ & 32 & 0 & $98 \pm 1.8(6)$ & $4.00 \pm 0.06$ & $0.041 \pm 0.004$ & $107 \pm 3.0$ & $26 \pm 1.0$ & $215 \pm 19.0$ \\
\hline $\begin{array}{l}\mathrm{F}, 18 \mathrm{hr} \text {; last inj. ISO } 36 \\
\mathrm{hr} \text { before sacrifice }\end{array}$ & 37 & 32 & $335 \pm 2.0(3)$ & $5.00 \pm 0.50$ & $0.018 \pm 0.001$ & $67 \pm 1.0$ & $38 \pm 1.0$ & $56 \pm 10.0$ \\
\hline $\begin{array}{l}\mathrm{F}, 18 \mathrm{hr} \text { : last inj. saline } 36 \\
\text { hr before sacrifice }\end{array}$ & 37 & 0 & $146 \pm 2.0(3)$ & $10.0 \pm 1.0$ & $0.068 \pm 0.005$ & $103 \pm 2.0$ & $24 \pm 1.0$ & $65 \pm 11.0$ \\
\hline $\begin{array}{l}\mathrm{F}, 19 \mathrm{hr} \text {; last inj. ISO } 36 \\
\mathrm{hr} \text { before sacrifice }\end{array}$ & 51 & 49 & $430 \pm 12.0(5)$ & $8.0 \pm 0.60$ & $0.019 \pm 0.001$ & $108 \pm 2.4$ & $43 \pm 2.7$ & $143 \pm 10.9$ \\
\hline $\begin{array}{l}\text { F. } 19 \text { hr: last inj. saline } 36 \\
\text { hr before sacrifice }\end{array}$ & 51 & 0 & $152 \pm 10.0(6)$ & $15.0 \pm 1.2$ & $0.100 \pm 0.010$ & $130 \pm 3.2$ & $20 \pm 1.2$ & $220 \pm 5.0$ \\
\hline $\begin{array}{l}\mathrm{F}, \mathrm{I} 8 \mathrm{hr} \text { : last inj. ISO } 15 \\
\text { days before sacrifice }\end{array}$ & 66 & 49 & $269 \pm 37.4(6)$ & $14.0 \pm 2.0$ & $0.050 \pm 0.010$ & $113 \pm 9.1$ & $28 \pm 2.6$ & $180 \pm 3$ \\
\hline $\begin{array}{l}\mathrm{F}, 18 \mathrm{hr} \text { : last inj. saline } 15 \\
\text { days before sacrifice }\end{array}$ & 64 & 0 & $207 \pm 25.3(6)$ & $17.0 \pm 1.7^{*}$ & $0.070 \pm 0.010^{*}$ & $131 \pm 3.7$ & $17 \pm 8.7$ & $230 \pm 5$ \\
\hline
\end{tabular}

${ }^{1}$ Values are means \pm SE: numbers in parentheses refer to no. of rats. F: food removed for interval stated. Flow rate is expressed as volume per min or volume per min per $\mathrm{mg}$ of wet tissue: concentration of amylase is expressed as milligrams of reducing substance formed per mg saliva, where $1 \mathrm{mg}$ $=1 \mu \mathrm{l}$. In each age group, the values for the experimental animals differed significantly $(P<0.05)$ from the controls: when there was no statistically significant difference, this is noted by the presence of an asterisk $\left({ }^{*}\right)$ next to the experimental group.

per mg gland) less than one-third that of controls. Na concentration of the isoproterenol-treated glands was $69 \pm 1 \mathrm{mEq} /$ liter and $\mathrm{K}, 38 \pm 1 \mathrm{mEq} /$ liter. The levels in controls differed sharply from these and were very much more like those of adult rats, being, respectively, $103 \pm 2.24 \pm 1$ (8).

When duration of isoproterenol-treatment was continued for longer intervals (from 2 days of age to 50 days of age), size of the isoproterenol-treated glands was again 3 times greater than that of controls, but volume of saliva produced by the controls was nearly double that of isoproterenol-treated glands. The difference between flow rate of controls and isoproterenol-treated rats (based on volume per min per $\mathrm{mg}$ of gland), was therefore greatly magnified. Na concentration of controls was at normal adult levels, whereas that of the isoproterenol-treated glands was still somewhat less (108 as compared with $130 \mathrm{mEq} /$ liter). However, $\left[\mathrm{K}^{+}\right]$was markedly affected by the isoproterenol treatment and was $43 \pm 2.7 \mathrm{mEq} /$ liter as compared with levels of $20 \pm 1.2$ for controls. Amylase concentration of the isoproterenol-treated animals was also only one-half that of controls.

These isoproterenol-induced effects were to some extent reversible. Cessation of isoproterenol treatment for 15 days caused a decrease in gland size to levels that were only somewhat higher than those of control glands. Volume returned to nearly normal levels, and although $\mathrm{Na}$ and $\mathrm{K}$ concentrations were closer to normal than before isoproterenol cessation, a complete return to normal levels was not effected.

\section{DISCUSSION}

Previous work had suggested that chronic isoproterenol administration led to accelerated morphological and biochemical development $(1,3,8,9)$. The present data again show the significant enhancement of size induced by the isoproterenol treatment but development of secretory function was inhibited. K concentration of the saliva from the isoproterenol-treated animals remained elevated and thus continued to resemble levels of the undeveloped parotid $(6,7)$. Na remained lower than that of controls and it also therefore resembled a gland that is less mature than the controls
$(6,7)$. Even the amount of fluid secreted was less than that of controls. In this case, the volume of saliva per min was in fact a more accurate indicator of secretory changes than volume per min per $\mathrm{mg}$ gland. Amylase concentration was also less in the saliva of the isoproterenol-treated than in that of controls.

All of these facts suggest that isoproterenol inhibits rather than accelerates development of secretory capacity. However, the cause of effects on secretion of $\mathrm{Na}, \mathrm{K}$ and water may be different from the effects on amylase secretion. For example, in the postweanling rat treated with isoproterenol for only 8 days, there is a 4 -fold increase in size of acinar cells and gland, and since the total amount of amylase of this gland is the same as that of the control, the concentration of amylase per unit of cytoplasm is also reduced to one-fourth of control levels (5). Amylase levels in the saliva show the same degree of reduction from controls (one-fourth) and thus the two change in parallel. It is possible that in the enlarged acinar cell the number of receptor sites is not changed from that of the normal gland but are more distant from each other. Accordingly, the stimulating agent may activate fewer receptors, on any or all acinar cells, and therefore less amylase is secreted. When the isoproterenol has been administered for a large part of the postnatal period, amylase levels of the secretion are not much lower than those of control glands, and show less direct relationship to the level of glandular amylase. Thus, an effect on spatial distribution of receptor sites may be involved in this condition also.

The mechanism of the inhibition of electrolyte and water secretion also may partially be a reflection of the altered size of the individual acinar cells but in addition it is probably related also to the marked compression of striated ducts that occurs with isoproterenol-induced gland enlargement (5). In either case, the ability of the ducts to reabsorb $\mathrm{Na}$ and secrete $\mathrm{K}$ is less developed than normally, and accordingly, the characteristics of the secretion resemble those of a more immature gland. Recent work on granule distribution of immature parotid chronically stimulated with isoproterenol also has provided evidence that prolonged isoproterenol treatment may actually produce a gland that in many respects shows a reversion to a more primitive structure $(7,8)$. The accen- 
tuation of the short term, isoproterenol-induced inhibitory effects on secretion when isoproterenol treatment is excessively prolonged emphasizes the fact that an actual retardation of secretory capacity occurs.

Finally, there is the additional implication that the inducer (isoproterenol) must be present to cause effects on structure or function and that permanent effects do not normally occur.

\section{REFERENCES AND NOTES}

1. Barka. T.. Chang, W. W. L., and Van der Noen, H.: Stimulation of DNA synthesis by isoproterenol in rat submandibular gland during postnatal growth. Cell Tiss. Kinet.. 6: $135(1973)$

2. Jacoby. F.. and Leeson. C. R.: The postnatal development of the rat submaxillary gland. J. Anat. 9.3: 201 (1959)

3. Menaker, L., Sheetz., J. H., Cobb. C. M., and Navia. J. M.: Histological and salivary alterations in isoproterenol treated rat submandibular gland. Lab. Invest.. 30: 341. (1974).

4. Myers. V. C.. Free, A. H.. and Rosinski. E. E.: Studies on animal diastases. VI. The determination of diastase (amylase) in blood. J. Biol. Chem.. 154: 39 (1944).

Copyright (1) 1978 International Pediatric Research Foundation, Inc. $0031-3998 / 78 / 1206-0726502.00 / 0$
5. Schneyer, C. A.: Premature increases in amylase in postnatal rat parotid with chronic isoproterenol. Proc. Soc. Exp. Biol. Med., 155: 440 (1977).

6. Schneyer, C. A., and Hall, H. D.: Autonomic regulation of the immature and adult rat parotid. In: L. H. Schneyer and C. A. Schneyer: Secretory Mechanisms of Salivary Glands. pp. 157-177 (Academic Press, Inc., New York. 1967).

7. Schneyer, C. A., and Hall, H. D.: Time course and autonomic regulation of development of secretory function of rat parotis. Amer. J. Physiol., 214: 808 (1968).

8. Schneyer, C. A., and Schneyer, L. H.: Secretion by salivary glands deficient in acini. Amer. J. Physiol., 201: 1939 (1961)

9. Schneyer, C. A., and Shackleford, J. M.: Accelerated development of salivary glands of early postnatal rats following isoproterenol. Proc. Soc. Exp. Biol. Med., I12: 320 (1963).

10. Sheetz, J. M.: Ph.D. thesis. A study of isoproterenol induced developmental alterations in acinar secretory cells and saliva from rat submandibular salivary glands (1976).

11. This research was supported by USPHS Grant DE 02110 from the NIH

12. Requests for reprints should be addressed to: Dr. Charlotte A. Schneyer, Department of Physiology and Biophysics, University of Alabama in Birmingham, University Station. Birmingham, Alabama 35294, USA.

13. Received for publication August 2, 1977

14. Accepted for publication September 7, 1977. 